\title{
PENGGANTIAN PAKAN KOMERSIAL DENGAN KOMBINASI TEPUNG DAUN MENGKUDU DAN TEPUNG DAUN PEPAYA TERHADAP PERFORMANS AYAM PEDAGING
}

\author{
Damaryanto Widharto dan Diwi Acita Irawati
}

\author{
Akademi Peternakan Karanganyar (Apeka) \\ Jl. Lawu no. 115, Karanganyar (57716); Telp./Fax. 0271-495212; E-mail : damaryw@ymail.com
}

\begin{abstract}
Abstrak
Tujuan penelitian ini untuk mengetahui pengaruh penggantian pakan komersial dengan kombinasi tepung daun mengkudu dan tepung daun pepaya terhadap performans ayam pedaging. Materi yang digunakan yaitu 60 ekor day old chick dengan bobot badan rata-rata $35 \pm 1,2$ gram/ekor. Perlakuan yang diterapkan yaitu pemberian pakan komersial tanpa penggantian dengan kombinasi tepung daun mengkudu dan tepung daun pepaya (T-0); penggantian pakan komersial dengan kombinasi Tepung Daun Mengkudu sebanyak 1,5 $\%$ dan Tepung Daun Pepaya sebanyak 0,5\% (T-1); penggantian pakan komersial dengan kombinasi Tepung Daun Mengkudu sebanyak 1,0 \% dan Tepung Daun Pepaya sebanyak 1,0 \% (T-2); penggantian pakan komersial dengan kombinasi Tepung Daun Mengkudu sebanyak 0,5\% dan Tepung Daun Pepaya sebanyak $1,5 \%$ (T-3). Variabel yang diamati adalah konsumsi pakan, pertambahan bobot badan harian, dan konversi pakan. Hasil penelitian menunjukkan penggantian pakan komersial dengan kombinasi tepung daun mengkudu dan tepung daun pepaya dapat menurunkan konsumsi pakan, meningkatkan pertambahan bobot badan dan memberikan nilai konversi pakan yang lebih baik. Konsumsi pakan untuk masing-masing perlakuan yaitu 67,01 (T0), 61,81 (T1), 60,00 (T2) dan 64,38 g/ekor/hari (T3), pertambahan bobot badan yaitu 44,69 (T0), 48,69 (T1), 47,39 (T2) dan 51,08 g/ekor/hari (T3), sedangkan untuk nilai konversi pakan yaitu 1,51 (T-0), 2,28 (T-1), 1,27 (T2) dan 1,26 (T-3). Kesimpulan dari penelitian ini yaitu penggantian pakan komersial dengan kombinasi tepung daun mengkudu dan tepung daun pepaya mampu meningkatkan perormans ayam broiler.
\end{abstract}

Kata kunci: Pakan komersial, Tepung daun mengkudu, Tepung daun pepaya dan Performans.

\section{Abstract}

The research was conducted to know influence of commercial feed substitution with mengkudu (Morinda citrifolia $L$ ) and pepaya (Carica papaya $L$ ) leaves flour combination in performance of broiler chicken. The research use 60 day old chick of broilers which were devided into 4 treatments, that is T-0 were given commercial feed without substitution, T-1 were given commercial feed with substitution of Morinda citrifolia $L$. $(1.5 \%)$ and Carica papaya L. $(0.5 \%)$, T-2 were given commercial feed with substitution of Morinda citrifolia $L$. $(1.0 \%)$ and Carica papaya L. (1.0\%) and T-3 were given commercial feed with substitution of Morinda citrifolia L. (0.5\%) and Carica papaya L. (1.5\%). The variables observed feed consumption, average daily gain, and feed conversion. The result showed that given commercial feed with substitution of mengkudu (Morinda citrifolia $L$ ) and pepaya (Carica papaya $L$ ) leaves flour combination can decrease of feed consumption, increase of average daily gain and provide better feed conversion values. Feed consumption is 67,01 (T0), 61,81 (T1), 60,00 (T2) dan 64,38 g/head/day (T3), average daily gain 44,69 (T0), 48,69 (T1), 47,39 (T2) dan 51,08 g/head/day (T3), and feed conversion 1,51 (T-0), 2,28 ( T-1), 1,27 (T2) dan 1,26 (T-3). Research conclusion is substution of mengkudu (Morinda citrifolia $L$ ) and pepaya (Carica papaya $L$ ) leaves flour combination in commercial feed can improve performance of broiler chicken.

Keywords: commercial feed, mengkudu and pepaya leaves flour and performance.

\section{PENDAhUlUan.}

Ayam broiler merupakan strain ayam hasil rekayasa genetik dengan ciri khas pertumbuhan yang cepat, sehingga dapat dipanen pada usia yang relatif muda dengan menghasilkan daging yang optimal. Biaya terbesar pada usaha ayam broiler adalah biaya pakan dibandingkan dengan biaya lainnya, sehingga perlu penyediaan bahan pakan yang baik untuk dapat mendukung pertumbuhan secara optimal sehingga mampu pencapaian berat badan maksimal. Bahan pakan yang memiliki potensi sebagai obat herbal (efek farmakologis) yang ditujukan untuk meningkatkan kesehatan dan pertumbuhan yaitu daun mengkudu (Morinda 
Agrisaintifika

citrifolia L.) dan daun pepaya (Carica papaya L.).

Apriyantono dan Farid

melaporkan bahwa daun dan akar mengkudu mengandung senyawa antrakuinon (damnacanthal) yang berfungsi sebagai antiseptik, antibakteri, antikanker dan meningkatkan daya tahan tubuh. Daun muda mengkudu secara in vitro mempunyai aktivitas anthielmintik, cukup baik melawan cacing Ascaris lumbricoides yang ada pada usus (Darusman, 2002). Daun mengkudu juga mengandung xeronine yang dikenal dapat membantu penyerapan protein (Bangun dan Sarwono, 2002). Wardiny (2006), menyatakan bahwa tepung daun mengkudu mengandung protein kasar $22,1 \%$, Ca 10,30\%, Fe 437 ppm, Zn 35,80 ppm dan $B$-karoten $161 \mathrm{ppm}$, yang dapat membuat ayam lebih cepat dewasa kelamin, produksi telur meningkat, konversi ransum menurun, dan pertambahan bobot badan meningkat karena adanya kandungan $B$-karoten, Fe dan Zn. Djauhariya dan Tirtoboma (2001), menyatakan bahwa senyawa-senyawa dalam mengkudu sangat aktif dalam menguatkan sistem kekebalan tubuh, memperbaiki fungsi sel dan mempercepat regenerasi sel-sel yang rusak seperti senyawa xeronin, proxeronin, proxeronase, serotonin, zat anti kanker (damnacanthal), scopoletin, sumber vitamin C, anti oksidan, mineral, protein, enzim, alkaloid dan fitronutrien lainnya. Murdiati, et.al., (2000) menyatakan bahwa fraksi kloroform yang mengandung alkaloid dan antrakuinon yang ada pada daun dan buah mengkudu mempunyai aktivitas anthelmintes yang terbesar.

Daun pepaya mengandung senyawa yang dapat mempermudah kerja usus dan berguna untuk proses pencernaan (Kamaruddin dan Salim, 2003). Daun pepaya juga mengandung enzim papain yang memiliki kemampuan membentuk protein baru (plastein) dan enzim proteolitik yang dapat meningkatkan efisiensi proses pencernaan. Menurut Ardina (2007) pada daun pepaya terkandung enzim papain yang memiliki sifat sebagai antimikrobial yang menghambat kinerja beberapa mikroorganisme serta memiliki alkaloid yang berfungsi sebagai antibakteri. Komponen aktif B karoten pada daun pepaya dapat sebagai antioksidan (Sutama, 2008). Hasil penelitian Hamzah (2019), menunjukkan bahwa penambahan tepung daun pepaya dapat memperbaiki konsumsi pakan, bobot badan dan konversi pakan ayam buras.

\section{BAHAN DAN METODE}

\section{Bahan Penelitian}

Materi penelitian yang dipergunakan terdiri dari bahan-bahan dan alat, yaitu :

Bahan yang dipergunakan dalam penelitian ini yaitu :

a. Anak ayam pedaging starin Ross umur 1 hari (Day Old Chick) yang diperoleh dari Poultry Shop di Karanganyar sebanyak 60 ekor dengan rata-rata bobot awal 34,5 gram per ekor.

b. Pakan komersial berupa konsentrat BR-1 produksi PT. Japfa Comfeed Indonesia.

c. Tepung daun mengkudu dan Tepung daun pepaya

Alat yang dipergunakan dalam penelitian ini

yaitu :

a. Kandang kelompok ulangan sebanyak 12 unit, dengan ukuran 0,7 x 1 meter

b. Tempat pakan dan minum sebanyak 12 unit

c. Timbangan digital sebanyak 1 unit.

\section{Metode Penelitian}

Metode penelitian yang dilakukan adalah metode eksperimen dengan desain yang digunakan Rancangan Acak Lengkap (RAL). Anak ayam umur 1 hari sebanyak 60 ekor, dibagi secara acak ke dalam 4 perlakuan, dan setiap perlakuan terdiri dari 3 sub ulangan dengan jumlah ayam masing-masing 5 ekor. Perlakuan dalam penelitian, yaitu :

1. Perlakuan kontrol (T-0), yaitu kelompok ayam yang diberi pakan komersial tanpa penggantian dengan kombinasi tepung daun mengkudu dan tepung daun pepaya. 
Agrisaintifika

Jurnal Ilmu-Ilmu Pertanian

Vol. 5, No. 1, 2021

Widharto \& Irawati. 2021

2. Perlakuan pertama ( $\mathrm{T}-1)$, yaitu kelompok ayam yang diberi pakan komersial dengan penggantian kombinasi Tepung Daun Mengkudu sebanyak 1,5\% dan Tepung daun Pepaya sebanyak $0,5 \%$ dari ransum basal.

3. Perlakuan ke-dua (T-2), yaitu kelompok ayam yang diberi pakan komersial dengan penggantian kombinasi Tepung Daun Mengkudu sebanyak $1 \%$ dan Tepung Daun Pepaya sebanyak $1 \%$ dari ransum basal.

4. Perlakuan ke-tiga (T-3), yaitu kelompok ayam yang diberi pakan komersial dengan penggantian kombinasi Tepung Daun Mengkudu sebanyak $0,5 \%$ dan Tepung Daun Pepaya sebanyak $1,5 \%$ dari ransum basal.

Tabel 1. Nilai gizi bahan pakan penelitian

\begin{tabular}{|c|c|c|c|c|}
\hline \multirow{3}{*}{\multicolumn{2}{|c|}{ Zat Gizi }} & \multicolumn{3}{|c|}{ Bahan Pakan } \\
\hline & & \multirow[t]{2}{*}{$\begin{array}{c}\text { Konsentrat } \\
\text { 1) }\end{array}$} & \multicolumn{2}{|c|}{$\begin{array}{l}\text { Daun } \\
\text { mengkudu } \\
\text { 2) }\end{array}$} \\
\hline & & & \multicolumn{2}{|r|}{$\%$} \\
\hline \multicolumn{2}{|c|}{$\begin{array}{l}\text { 1. Bahan Kering } \\
\text { (BK) } \\
\text { 2. Protein Kasar }\end{array}$} & \multicolumn{2}{|l|}{88,00} & 89,95 \\
\hline \multirow{2}{*}{\multicolumn{2}{|c|}{$\begin{array}{l}\text { (PK) } \\
\text { 3. Serat Kasar }\end{array}$}} & \multicolumn{2}{|l|}{21,00} & 15,92 \\
\hline & & \multicolumn{2}{|l|}{4,00} & 22,12 \\
\hline \multicolumn{2}{|c|}{ 4. Kalsium (Ca) } & \multicolumn{2}{|l|}{-} & 2,02 \\
\hline \multicolumn{2}{|c|}{ 5. Phospor (P) } & \multicolumn{2}{|c|}{ 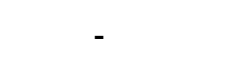 } & - \\
\hline \multicolumn{5}{|c|}{$\begin{array}{l}\text { Sumber : 1) PT. Japfa Comfeed Indonesia } \\
\text { 2) Febriani (2010) } \\
\text { 3) Widyaningrum (2012) }\end{array}$} \\
\hline \multicolumn{5}{|c|}{$\begin{array}{l}\text { 2. Komposisi dan perhitungan nilai gizi } \\
\text { n penelitian }\end{array}$} \\
\hline \multirow[t]{2}{*}{ n Pakan } & \multicolumn{4}{|c|}{$\begin{array}{l}\text { Komposisi Pakan } \\
\text { Penelitian (\%) }\end{array}$} \\
\hline & $\mathrm{T}-0$ & $\mathrm{~T}-1$ & $\mathrm{~T}-2$ & $\mathrm{~T}-3$ \\
\hline $\begin{array}{l}\text { isentrat } \\
\text { un }\end{array}$ & 100 & 98 & 98 & 98 \\
\hline kkudu & - & 0,5 & 1 & 1,5 \\
\hline un pepaya & - & 1,5 & 1 & 0,5 \\
\hline Pakan & $\mathrm{T}-0$ & $\mathrm{~T}-1$ & T-2 & T-3 \\
\hline & 88,00 & 88,00 & 88,01 & 88,03 \\
\hline
\end{tabular}

2. Protein

Kasar (\%) $\quad 21,00 \quad 20,91 \quad 20,91 \quad 20,90$

3. Serat Kasar (

$\begin{array}{lllll}\%) & 4,00 & 4,27 & 4,30 & 4,33\end{array}$

\section{Variabel Penelitian}

a. Sebagai variable control (T-0) adalah pemberian pakan komersial tanpa adanya penggantian dengan kombinasi Tepung Daun Mengkudu dan Tepung Daun Pepaya.

b. Sebagai variable independent adalah penggantian pakan komersial dengan kombinasi Tepung Daun Mengkudu dan Tepung Daun Pepaya sebanyak $2 \%$ dari ransum basal.

c. Sebagai variable dependent adalah Konsumsi Pakan, Pertambahan Bobot Badan Harian dan Konversi Pakan.

\section{Analisis Data}

Data yang diperoleh selanjutnya Daun dianalisis statistik menggunakan pepaya arogram SPSS for Windows Release 15.0 dan perbedaan antar perlakuan ditakukan uji lanjut duncant multiple 87,37 range test (DMRT).

\section{6,77ASIL DAN PEMBAHASAN Konsumsi pakan}

16,28 Hasil pengamatan selama penelitian 4ê7tang pengaruh substitusi pakan komersial Qdểgan tepung daun mengkudu dan tepung daun pepaya terhadap konsumsi pakan ayam broiler, sebagaimana pada tabel 3.

Tabel. 3. Data rata-rata konsumsi pakan (g/ekor/hari)

\begin{tabular}{lcccc}
\hline \multirow{2}{*}{ PERLAKUAN } & $\mathrm{T}-0$ & $\mathrm{~T}-1$ & $\mathrm{~T}-2$ & $\mathrm{~T}-3$ \\
\cline { 2 - 5 } & \multicolumn{4}{c}{$\mathrm{g} /$ ekor/hari } \\
\hline Ulangan-1 & 68,25 & 58,35 & 56,10 & 61,15 \\
Ulangan-2 & 65,60 & 64,53 & 63,53 & 66,95 \\
Ulangan-3 & 67,18 & 62,55 & 60,38 & 65,03 \\
\hline \multirow{5}{*}{ Rata-rata } & $67,01^{\mathrm{a}}$ & $61,81^{\mathrm{b}}$ & $\mathrm{b}$ & 60,00 \\
\hline \multicolumn{4}{c}{ Keterangan : Berbeda nyata (Sig.081) }
\end{tabular}

Hasil uji statistik penggantian pakan komersial dengan tepung daun mengkudu 
Agrisaintifika

dan tepung daun pepaya terhadap konsumsi pakan menunjukkan hasil berbeda nyata (Sig.081). Hasil uji lanjut Duncant memperlihatkan perbedaan diantara perlakukan, yaitu T0 berbeda nyata dengan T1, T2 dan T3. Hal ini berarti penggantian pakan komersial dengan kombinasi tepung daun mengkudu dan tepung daun pepaya yang memberikan pengaruh secara nyata pada konsumsi pakan. Ditinjau dari aspek nutrisi dalam pakan penelitian maka penggantian sebagian pakan komersial dengan tepung daun mengkudu dan tepung daun pepaya sampai level $2 \%$ meningkatkan kandungan serat kasar (SK) dan metabolis energi (ME) pakan.

Kandungan serat kasar dalam pakan penelitian yaitu 4,00 (T0), 4,27 (T1), 4,30 (T2) dan 4,33\% (T3). Hal ini sesuai dengan pendapat Ichwan (2005) yang menyatakan bahwa faktor-faktor yang mempengaruhi konsumsi pakan pada unggas adalah kandungan serat kasar dalam pakan, disamping kualitas dan palatabilitas pakan. Suciani, et al., (2011) menyatakan bahwa ayam broiler tidak dapat mencerna serat kasar yang terlalu tinggi yang akan menyebabkan efisiensi penggunaan zat-zat makanan mengalami penurunan. Serat kasar yang tinggi menyebabkan laju digesta semakin cepat, sehingga nilai kecernaan nutrisi lain mengalami penurunan yang keluar bersama eksreta dan mengakibatkan penurunan konsumsi ransum yang secara tidak langsung berpengaruh terhadap konsumsi protein.

Kandungan metabolis energi (ME) pada pakan perlakuan T-1 dan T-2 lebih tinggi dibandingkan dengan T-0, yaitu 3095,5 (T-1), 3077,6 (T-2) dan $3075 \mathrm{kkal} / \mathrm{kg}$ (T-0). Tingginya kandungan energi dalam pakan menyebabkan penurunan konsumsi pakan. Hal tersebut sesuai pendapat Tampubolon dan Bintang (2012) menyatakan bahwa jumlah konsumsi ransum dipengaruhi oleh kandungan energi didalam pakan. Zuprizal (2006) menyatakan bahwa pakan yang rendah kandungan energi metabolisnya akan meningkatkan jumlah pakan yang dikonsumsi dan sebaliknya pakan yang tinggi kandungan energi metabolisnya menyebabkan turunnya jumlah pakan yang dikonsumsi, dan Aisjah $d k k$, (2007) yang menyatakan bahwa kandungan energi yang tinggi dalam pakan akan menekan konsumsi pakan.

Ditinjau dari aspek sinergitas zat aktif yang terdapat dalam tepung daun mengkudu dan tepung daun pepaya maka pada komposisi yang sebanding (perlakuan T2; 1\% TDM dan 1\% TDP) memiliki pengaruh yang besar dalam meningkatkan efisiensi pakan, diikuti oleh perlakuan T1 dan T3. Pada perlakuan T1 (1,5\% TDM : 0,5\% TDP) zat aktif yang lebih banyak berperan dari tepung daun mengkudu yang memiliki efek pada tingkat kesehatan ternak. Hal ini sesuai pendapat Djauhariya dan Tirtoboma (2001), menyatakan bahwa senyawa-senyawa dalam mengkudu sangat aktif dalam menguatkan sistem kekebalan tubuh, memperbaiki fungsi sel dan mempercepat regenerasi sel-sel yang rusak. Pada perlakuan T3 (0,5\% TDM : 1,5\% TDP) zat aktif yang lebih banyak berperan dari tepung daun pepaya yang memiliki efek pada meningkatkan efisiensi proses pencernaan. Menurut Kamaruddin dan Salim, 2003, bahwa daun pepaya mengandung senyawa yang dapat mempermudah kerja usus dan berguna untuk proses pencernaan.

\section{Pertambahan bobot badan harian (PBBH)}

Hasil pengamatan selama penelitian tentang pengaruh penggantian pakan komersial dengan tepung daun mengkudu dan tepung dan pepaya terhadap pertambahan bobot badan ayam broiler, sebagaimana pada tabel 4 .

Tabel. 4. Data rata-rata pertambahan bobot badan

\begin{tabular}{lcccc}
\hline \multirow{2}{*}{ PERLAKUAN } & T-0 & T-1 & T-2 & T-3 \\
\cline { 2 - 5 } & \multicolumn{4}{c}{ g/ekor/hari } \\
\hline Ulangan-1 & 40,93 & 51,79 & 45,79 & 50,71 \\
Ulangan-2 & 47,50 & 44,82 & 50,07 & 48,25 \\
Ulangan-3 & 45,64 & 49,46 & 46,32 & 54,29 \\
\hline Rata-rata & 44,69 & 48,69 & 47,39 & 51,08 \\
\hline \multicolumn{4}{c}{ Keterangan : Berbeda nyata (Sig.166) }
\end{tabular}


Rata-rata pertambahan bobot badan harian $(\mathrm{PBBH})$ masing-masing perlakuan sebesar $\mathrm{T} 0=44,69 ; \quad \mathrm{T} 1=48,69 ; \quad \mathrm{T} 2=47,39$; T3=51,08 gram/ekor/hari. Hasil uji statistik menunjukkan bahwa penggantian pakan komersial dengan kombinasi tepung daun mengkudu dan tepung daun pepaya berbeda nyata (Sig. 166). Hasil ini menunjukkan bahwa penggantian pakan komersial dengan kombinasi tepung daun mengkudu dan tepung daun papaya sampai level $2 \%$ mampu memperbaiki performans ayam pedaging. Hasil uji lanjut Duncant menunjukkan bahwa T0 berbeda nyata dengan T1, T2 dan T3 sedangkan $\mathrm{T} 1$ berbeda tidak nyata dengan T2, tetapi T3 berbeda nyata dengan T1 dan T2. Hal ini berarti bahwa hanya penggantian pakan komersial dengan kombinasi tepung daun mengkudu dan tepung daun papaya dengan komposisi 0,5\% TDM dan 1,5\% TDP (T3) yang pertambahan bobot badan harian (PBBH) paling baik dibandingkan dengan T1 dan T2. Hasil ini dimungkinkan karena zat aktif yang terdapat dalam tepung daun papaya (TDP) lebih besar pengaruhnya pada konsumsi pakan dan pertumbuhan.

Menurut Ardina (2007) pada daun pepaya terkandung enzim papain yang berfungsi sebagai anti mikrobial dan alkaloid yang berfungsi sebagai antibakteri. Enzim papain juga memiliki sifat sebagai anti mikrobial yang dapat menghambat kinerja beberapa mikroorganisme. Komponen aktif $B$ karoten (pro-vitamin A) pada daun pepaya dapat sebagai anti oksidan (Sutama, 2008). Daun Carica papayamengandung alkaloid, saponin, tannin, glycoside dan flavonoid (Adachukwu et al., 2013). Daun pepaya kaya akan enzime proteolitik, yaitu papain, khimopapain A dan B dan papaya peptidase (Yadava, et al., 1990). Papain adalah suatu senyawa yang membantu proses pencernaan alami yang efektif yang memecah protein dan membersihkan saluran pencernaan (Poulter and Caygill, 1985).

Konsumsi sangat berpengaruh pada pertumbuhan ayam karena bila konsumsi pakan rendah akan menyebabkan laju pertumbuhan dari ayam tersebut menjadi terhambat sehingga pertambahan bobot badannya akan menjadi rendah, dan sebaliknya bila konsumsi pakan tinggi akan menyebabkan laju pertumbuhan dari ayam tersebut menjadi cepat sehingga pertambahan bobot badannya akan menjadi tinggi pula. Pertambahan bobot badan broiler berkaitan dengan pakan yang dikonsumsi, apabila konsumsi pakan terganggu maka akan dapat mengganggu pertambahan bobot badan broiler. Faktor-faktor yang mempengaruhi konsumsi pada unggas adalah kandungan serat kasar dalam pakan, tingkat kualitas pakan, dan palatabilitas atau cita rasa pakan. Widodo (2009) menyatakan bahwa pakan yang dikonsumsi oleh ternak unggas sangat menentukan pertambahan bobot badan sehingga berpengaruh terhadap efisiensi suatu usaha peternakan.

\section{Konversi pakan}

Mazi, K., (2013) menyatakan bahwa konversi pakan merupakan salah satu standar produksi untuk menilai efisiensi pakan yang dikonsumsi ternak menjadi daging atau sebagai patokan tingkat produktifitas ayam. Rata-rata konversi pakan pada keempat perlakuan dapat dilihat pada tabel 5 berikut ini.

Tabel 5. Rata-Rata Konversi Pakan

\begin{tabular}{ccccc}
\hline \multirow{2}{*}{ Ulangan } & \multicolumn{4}{c}{ Perlakuan } \\
\cline { 2 - 5 } & T0 & T1 & T2 & T3 \\
\hline $\begin{array}{l}\text { Ulangan } \\
1\end{array}$ & 1,67 & 1,13 & 1,23 & 1,21 \\
$\begin{array}{l}\text { Ulangan } \\
2\end{array}$ & 1,38 & 1,44 & 1,27 & 1,39 \\
$\begin{array}{l}\text { Ulangan } \\
\text { 3 }\end{array}$ & 1,47 & 1,26 & 1,30 & 1,20 \\
\hline Rata-rata & 1,51 & 1,28 & 1,27 & 1,26 \\
\hline
\end{tabular}

Rata-rata konversi pakan ayam broiler pada masing-masing perlakuan dari yang paling kecil ke paling besar adalah $\mathrm{T} 3=1,26$; $\mathrm{T} 2=1,27 ; \mathrm{T} 1=1,28 ; \mathrm{T} 0=1,51$. Hal ini menunjukkan bahwa penggantian pakan komersial dengan kombinasi tepung daun 
mengkudu (TDM) dan tepung daun pepaya (TDP) berpengaruh terdadap korversi pakan. Pengaruh tersebut di atas dikarenakan penggantian TDM dan TDP berpengaruh juga terhadap konsumsi dan pertabahan bobot badan harian $(\mathrm{PBBH})$. Konsumsi pakan pada kelompok perlakuan T1, T2 dan T3 mengalami penurunan dibandingkan dengan perlakuan T0 (tabel 3), dan memiliki tingkat pertumbuhan yang lebih baik dibandingkan dengan perlakuan T0 (tabel 4) sehingga menghasilkan nilai konversi pakan yang lebih rendah. Dengan kata lain bahwa pada perlakuan T-1, T2 dan T-3 memiliki tingkat efisiensi pakan yang lebih baik daripada perlakuan T-0.

Lacy dan Vest, (2004), menyatakan bahwa nilai konversi pakan merupakan suatu ukuran untuk menilai efisiensi dalam penggunaan ransum, semakin rendah konversi ransum maka akan semakin efisien karena semakin sedikit jumlah ransum yang dibutuhkan untuk menghasilkan pertambahan bobot badan dalam jangka waktu tertentu. Hasil penelitian ini menunjukkan bahwa pada perlakuan T0 dibutuhkan pakan sebanyak $1,51 \mathrm{~kg}$ untuk menghasilkan kenaikan bobot badan sebesar $1 \mathrm{~kg}$, sedangkan untuk T1 dibutuhkan pakan sebanyak $1,28 \mathrm{~kg}$, untuk T2 dibutuhkan pakan sebanyak 1,27 kg dan untuk T3 dibutuhkan pakan sebanyak 1,26 kg. Tingkat efisiensi yang dicapai dari masing-masing perlakuan yaitu sebesar 15,23\% (T1), 15,89\% (T2) dan 16,56\% (T2) dibandingkan dengan perlakuan TO.

\section{SIMPULAN}

Memperhatikan hasil penelitian dan uraian pembahasan maka dapat disimpulkan sebagai berikut :

1. Penggantian pakan komersial dengan kombinasi tepung daun mengkudu dan tepung daun pepaya mampu menekan konsumsi pakan, meningkatkan pertambahan bobot badan harian dan memberikan nilai konversi pakan yang lebih baik.
2. Penggantian pakan komersial dengan kombinasi tepung daun mengkudu dan tepung daun pepaya mampu meningkatkan performans ayam broiler.

\section{DAFTAR PUSTAKA}

Adachukwu, I. P., O. O. Ann and E. U. Faith. 2013. Phytochemical analysis of pawpaw (Carica papaya) leaves. Int. J. Life Sci. Biotechnol. Pharma Res., 2: (3).

Aisjah, T., R.Wiradimadja dan Abun., 2007. Suplementasi metionin dalam ransum berbasis lokal terhadap imbangan efisiensi protein pada ayam pedaging. Artikel IImiah Jurusan IImu Nutrisi dan Makanan Ternak, Fakultas Peternakan, Universitas Padjajaran, Jatinangor, Bandung

Apriyantono, A. dan S. Farid. 2002, Mengkudu (Morinda Citrfolia Linn): Efek farmakologis dan teknologi pengolahannya. Saresehan Temu Saran Pengembangan Obat Tradisional Indonesia, Bogor.

Ardina, Y. 2007. Development of Antiacne Gel Formulation and Minimum Inhibitory Concentration Jurnal Sain Peternakan Indonesia Vol 9 No 1. Januari-Juni 2014 | 48 ISSN 19783000 Determination from Carica Papaya Leaves Extract (Carica papaya A Linn.). http://digilib.itb.ac.id/gdl.php.

Bangun, A.P. dan B. Sarwono. 2002. Sehat dengan ramuan tradisional, khasiat dan manfaat mengkudu. Jakarta : Agromedia Pustaka.

Darusman, L.K. 2002. Mengkudu (Morinda Citrifolia) : kandungan bahan aktif dan efek farmokologisnya. Lamongan : Makalah disampaikan pada pertemuan koordinasi dalam rangka pengembangan agribisnis tanam obat, 25-26 September 2002.

Hamzah, M.H. (2019). Pengaruh Pemberian Tepung Daun Pepaya Dalam Ransum 
Widharto \& Irawati. 2021

Pakan

Ayam Buras Terhadap Bobot Ayam Buras, Skripsi. Fapet. Universitas Nusantara PGRI. Kediri.

Ichwan. 2005. Membuat Pakan Ayam Ras Pedaging. PT. AgromediaPustaka. Jakarta.

Djauhariya, E. dan Tirtaboma, 2001. Mengkudu (Morinda citrifolia) Tanaman Obat Tradisional Multi Khasiat. Warta Penelitian dan Pengembangan Tanaman Industri: 7(1-2), Hal. 1-3.

Kamaruddin, M. dan Salim. 2003. Pengaruh Pemberian Air Perasan Daun Pepaya Pada Ayam : Respon Patofisilogik Hepar. Jurnal Sain Veterinet 20 (1) : $37-43$.

Lacy, M. dan L. R. Veast. 2004. Improving Feed Conversion in Broiler : A Guide for Growers. Spinger Science and Businsess Media Inc. New York.

Mazi, K., Supartini, N., dan Darmawan, H. 2013. Tingkat Konsumsi, Konversi dan Income Over Feed Cost pada Pakan Ayam Kampung dengan Penambahan Enzim Papain. (Thesis). Program Studi Peternakan, Fak. Pertanian. Univ. Tribhuwana Tunggadewi. Malang.

Murdiati, T.B., Adiwinata, G. dan D. Hildasari. 2000. Penelusuran Senyawa Aktif dari Buah Mengkudu (Morinda citrifolia) dengan Aktivitas Anthelmintik Terhadap Haemonchus contortus.
Jurnal IImu Ternak dan Veteriner 5(4): 255-259

Poulter, N.H. and J.C. Caygill, 1985. Production and utilization of papain-a proteolytic enzyme from Carica papaya L. Trop. Sci., 25: 123-137.

Sutama, I. N. S. 2008. Daun Pepaya dalam Ransum Menurunkan Kolesterol pada Serum dan Telur Ayam. Jurnal Veteriner 9 (3) : 152-156

Tampubolon., Bintang, P.P., 2012. Pengaruh imbangan energi dan protein ransumterhadap energi metabolis dan retensi nitrogen ayam broiler. Jurnal Fakultas Peternakan Universitas Padjajaran. Bandung.

Wardiny, 2006. Kandungan vitamin A, C dan kolesterol telur ayam yang diberi mengkudu (Morinda citrifolia) dalam ransum [tesis]. Bogor (ID): Institut Pertanian Bogor.

Widodo, W. 2009. Nutrisi dan Pakan Unggas Kontekstual. Universitas Muhammadiyah Malang, Malang.

Yadava, U. L., A. Janice, Burris and D. McGary. 1990. Papaya: A Potential annual crop under middleGeorgia conditions. In: J. Janick and J.E. Simons (Eds.), Advances in New Crops. Timber Press, Portland, pp: 364-366.

Zuprizal, 2006. Nutrisi unggas. Handout.Jurusan Nutrisi dan Makanan Ternak.Fakultas Peternakan. UGM Yogyakarta 